\title{
The Reign of Elizabeth I
}

Each volume in the 'Problems in Focus' series is designed to make available to students important new work on key historical problems and periods that they encounter in their courses. Each volume is devoted to a central topic or theme, and the most important aspects of this are dealt with by specially commissioned essays from scholars in the relevant field. The editorial Introduction reviews the problem or period as a whole, and each essay provides an assessment of the particular aspect, pointing out the areas of development and controversy, and indicating where conclusions can be drawn or where further work is necessary. An annotated bibliography serves as a guide for further reading. 


\section{PROBLEMS IN FOCUS SERIES}

TITLES IN PRINT

Church and Society in England: Henry VIII to James I edited by Felicity Heal and Rosemary O'Day

The Reign of James VI and I

edited by Alan G. R. Smith

The Origins of the English Civil War

edited by Conrad Russell

The Interregnum: The Quest for Settlement 1646-1660

edited by G. E. Aylmer

The Restored Monarchy 1660-1688

edited by J. R. Jones

Britain after the Glorious Revolution 1689-1714

edited by Geoffrey Holmes

Popular Movements, c. 1830-1850

edited by J. T. Ward

Europe's Balance of Power 1815-1848

edited by Alan Sked

The Edwardian Age: Conflict and Stability 1900-1914 edited by Alan O'Day

The Mid-Tudor Polity c. 1540-1560

edited by Jennifer Loach and Robert Tittler

Slavery and British Society 1776-1846

edited by James Walvin

Reactions to the English Civil War 1642-1649

edited by John Morrill

Britain in the Age of Walpole

edited by Jeremy Black

The Reign of Elizabeth I

edited by Christopher Haigh

British Imperialism in the Nineteenth Century

edited by C. C. Eldridge

FURTHER TITLES ARE IN PREPARATION 


\title{
The Reign of Elizabeth I
}

\author{
EDITED BY \\ CHRISTOPHER HAIGH
}

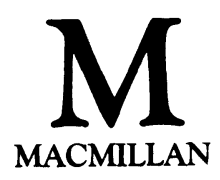


Introduction, Conclusion, editorial matter and Chapter 8 CC Christopher Haigh 1984; Chapter 1 (C) Norman L. Jones (C) 1984; Chapter 2 (C) Simon Adams 1984; Chapter 3 (C) G. R. Elton 1984; Chapter 4 (C) J. D. Alsop 1984; Chapter 5 (C) Penry Williams 1984; Chapter 6 (C) G. D. Ramsay 1984; Chapter 7 (C) Patrick Collinson 1984; Chapter 9 (C) Paul Slack 1984

All rights reserved. No reproduction, copy or transmission of this publication may be made without written permission.

No paragraph of this publication may be reproduced, copied or transmitted save with written permission or in accordance with the provisions of the Copyright Act 1956 (as amended).

Any person who does any unauthorised act in relation to this publication may be liable to criminal prosecution and civil claims for damages.

First published 1984

Published by

Higher and Further Education Division

MACMILLAN PUBLISHERS LTD

Houndmills, Basingstoke, Hampshire RG21 2XS

and London

Companies and representatives

throughout the world

Typeset by

Wessex Typesetters Ltd

Frome, Somerset

British Library Cataloguing in Publication Data

The Reign of Elizabeth I. - (Problems in focus)

1. Great Britain - History - Elizabeth, 1558-1603

I. Haigh, Christopher II. Series

942.05'5 DA355

ISBN 978-0-333-33963-3

ISBN 978-1-349-17704-2 (eBook)

DOI 10.1007/978-1-349-17704-2 


\section{Contents}

Preface vii

Introduction 1

CHRISTOPHER HAIGH

1 Elizabeth's First Year: The Conception and Birth of the Elizabethan Political World

NORMAN L. JONES

2 Eliza Enthroned? The Court and its Politics SIMON ADAMS

3 Parliament

G. R. ELTON

4 Government, Finance and the Community of the Exchequer

J. D. ALSOP

5 The Crown and the Counties

PENRY WILLIAMS

6 The Foreign Policy of Elizabeth I

G. D. RAMSA Y

7 The Elizabethan Church and the New Religion PATRICK GOLLINSON

8 The Church of England, the Catholics and the People

CHRISTOPHER HAIGH

9 Poverty and Social Regulation in Elizabethan England 
vi CONTENTS

Conclusion

CHR ISTOPHER HAIGH

List of Abbreviations

Bibliography

Notes and References

263

Notes on Contributors

289

Index

291 


\section{Preface}

ONE of the traditional functions of a preface is to explain what is and excuse what is not in a book, in the hope of defusing some of the ire of critics. This collection of essays was planned as a coherent whole: whether it became one is for the reader to judge. The volume aims to survey the composition and workings of the Elizabethan political system, and to examine how its institutions responded to the issues which most worried politicians and churchmen. Given these intentions, the most obvious gaps are the regulation of economic activity and the promotion of naval and colonial enterprise. The real reasons for the omissions are the necessary constraints of the 'Problems in Focus' series; the public justifications are the appearance of a splendid study of the Elizabethan economy (David Palliser's The Age of Elizabeth), and my conviction that, as Drake and Ralegh have long had more attention than they deserved, a little neglect would be salutary.

A second, and essential, role of a preface to a collective volume is to thank all those who made the editor's task easier (while remaining silent about any who made it more difficult!). The contributors to this book do not form a party (still less a faction): they share no common ideology, and are deliberately representative of a wide range of approaches and generations. I was lucky to recruit a team of authors willing to play in the positions I earmarked for them, and luckier still that my team-mates turned up for the match. I am grateful to them, and especially to Jim Alsop, who joined as a late substitute and still managed to score before the final whistle. The team management (Sarah Mahaffy, Vanessa Peerless and Valery Rose) proved encouraging and helpful, and their patience was exceeded only by that of the editor's wife and daughters. 